On the Political Economy of

Environmental Policy

Gebhard Kirchgässner and Friedrich Schneider

N ovember 2001 Discussion paper no. 2001-20 
Editor: $\quad$ Prof. Jörg Baumberger

University of St. G allen

Department of Economics

Bodanstr. 1

CH -9000 St. Gallen

Phone ++41712242241

Fax $\quad++41712242885$

Publisher: $\quad$ Forschungsgemeinschaft für $\mathrm{N}$ ationalökonomie

Email_joerg.baumberger@ unisg.ch an der Universität St. G allen

Dufourstrasse 48

$\mathrm{CH}-9000$ St. Gallen

Phone ++41712242300

Fax $\quad++41712242646$

Electronic Publication:

www.fgn.unisg.ch/public/public.htm 


\title{
On the Political Economy of Environmental Policy
}

\author{
Gebhard Kirchgässner and Friedrich Schneider
}

Authors' addresses:

Prof. D r. Gebhard Kirchgässner

Swiss Institut for International Economics and Applied

Economic Research

University of St. G allen and C ESifo

D ufourstrasse 48

9000 St. Gallen

Tel. $\quad++41712242340$

Fax $\quad++41712242298$

Email_Gebhard.Kirchgaessner@ unisg.ch

W ebsite www.siaw.unisg.ch/kirch/gki/kir.html

Prof. Dr. Friedrich Schneider

University of Linz

Institute of Economics

A-4040 Linz-Auhof

Tel. $\quad++4373224680$

Fax $\quad++43732246810$

Email friedrich.schneider@jk.uni-linz.ac.at

W ebsite www.uni-linz.at 


\begin{abstract}
In the past there was hardly any use of economic instruments in environmental policy, mainly command and control measures were used. More recently, ecological taxes became more popular and voluntary agreements have been proposed and implemented. Thus, the situation has changed at least somewhat, and we must ask what the reasons are for the (partly) new development and the wider acceptance of these instruments. The purpose of this paper is to give some answers on these questions using the Public Choice approach. To do so, we first present the main ideas of this approach to analyse environmental policy. Then we discuss the recent application of traditional market based instruments, environmental taxes and tradable permits as well as the increasing use of voluntary agreements. Taking all arguments together we have to conclude that the use of market based instruments in environmental policy has not increased very much and their impact on the actual situation of the environment is still rather low, but there is hope that there will be at least some further increase in the future.
\end{abstract}

\title{
Keywords
}

environmental policy, ecological taxes, tradable permits, voluntary agreements, voting behaviour, public bureaucracy, interest groups

\section{JEL Classification}

Q 00 


\section{Introduction}

"How the patient followed the doctor's orders" is the subtitle of a seminal paper by R.W. HAHN (1989) who chronicled the experience with both tradable permits as well as emission charges up to the late eighties in the U.S. and Europe. He showed that at this time some countries had made first attempts to include these incentive oriented instruments but that the actual use of these tools departed "from the role which economists have conceived for them" (p. 96.). Already earlier a literature started which tried to answer the somewhat changed question of "Why did the patient not follow the doctor's orders?", i.e. it tried to explain why despite of the many papers and books written by environmental economists in favour of market based instruments the actual environmental policy still mainly uses the 'bureaucratic instruments' of command and control. There are at least three groups of arguments which are given as possible reasons:

(i) Some authors have principal objections against the neo-classical model and/or the concept of homo economicus behind it. They see a possible alternative in the concept of ecological economics. ${ }^{1)}$

(ii) Some authors have no objections against the neo-classical approach or using the model of the homo economicus per se, but against the assumption of (pure) self-interest usually employed. $^{2)}$ They argue that politicians hesitate to apply environmental policy instruments which use (monetary) incentives because these might crowd out environmental ethics which is necessary in other areas of environmental policy.

(iii) Most authors use a Public Choice approach to explain why the application of incentive oriented instruments in environmental policy is neither in the interest of the public bureaucrats nor of the industries to be regulated. ${ }^{3)}$ If any instrument of environmental policy is used at all, both groups of actors have much stronger interests in applying traditional bureaucratic measures.

Out of these three groups, only the third one provides really convincing arguments which may explain the failure to introduce a market oriented environmental policy:

(i) The first group of authors are not only hardly convincing with their arguments, they use also - at least partly - contradictory arguments. It is true that ecological economics in using the concept of sustainability places more emphasis on 'natural' constraints of the economic process than traditional environmental economics. The concept of sustainabi-

1. See, e.g., F. SÖLLNER (1993).

2. See, e.g., S. Kelman (1981), H. Weck-Hannemann and B.S. Frey (1995), B.S. Frey and F. OberHOLZER-GEE (1996), or - more generally - F. HIRSCH (1976).

3. This approach goes back to B.S. FrEY (1972, pp. 134ff.) and J. BUCHANAN and G. TUlLOCK (1975). More recent papers are, e.g., P.B. Downing (1991), H.W. URsPrung (1992), B. DiJKstra and A. NentJes (1994), E. GAWEL (1994), G. KirChGÄSSNER (1994, pp. 479ff.), H. WECK-HANNEMANN (1994), K.W. ZIMMERMANN (1996), F. SCHNEIDER (1997), or F. SCHNEIDER and J. VOLKERT (1999). Papers which apply this approach to international environmental problems are, e.g., A.L. HILlMAN and H. URSPRUNG (1994), R.D. CONGLeton (1995), A. Michaelowa (1998) or A. ENDRES and M. FinUs (2000). 
lity can, however, be incorporated into models of (neo-classical) environmental economics without any problems. Thus, there is no systematic difference between these two areas in this respect. ${ }^{4)}$ Moreover, when it comes to the discussion of environmental policy, many of the authors who see themselves as ecological economists demand the use of environmental taxes according to the standard-price-approach of W.J. BAUMOL and W.E. OATES (1971), an approach which is clearly in the 'neoclassical' tradition. ${ }^{5)}$ In addition, there are no new instruments which have been proposed by the authors belonging to this group which have not yet been proposed before by traditional environmental economists. Thus, whatever the merits of this approach might be, it fails to explain why market based environmental instruments had only so few chances in the past to become part of environmental policy programs.

(ii) Secondly, the idea that market based environmental policy instruments have so far not been applied because of the anxiety that they might crowd out intrinsic motivation which is necessary to preserve the environment is also not very convincing. It is true that until the eighties environmental groups used such arguments: they argued against a 'commercialisation' of the environment and demanded bureaucratic instruments. However, the situation has changed; today these groups demand the use of market-based instruments, especially of 'ecological taxes'. There has been some use of such taxes in several countries in recent years, especially in small European countries. However, in most of these countries environmental groups are not strong enough to substantially change their national environmental policy. Moreover, the argument itself is hardly convincing. Intrinsic motivation can play a role for 'low-cost-decisions' ${ }^{6)}$ But the really important production and consumption decisions which have an environmental impact and could be influenced by environmental policy do not belong to this category. ${ }^{7)}$ In these situations, moral arguments which could refer to intrinsic motivation do - at the best - have an alibi function. On the other hand, where intrinsic motivation can play a role to protect the environment economic instruments are hardly applicable. (The same holds for bureaucratic instruments.) Thus, even if we accept the theoretical possibility of a crowding out of intrinsic motivation by instruments which provide monetary incentives this can hardly be expected to have much relevance in the area of environmental policy. Moreover, at least according to B.S. FREY (1997, p. 69), the possibility of a crowding out of intrinsic motivation is higher if bureaucratic instruments than if market based instruments are used because the latter are not only - in most cases - more efficient - but they give also the individuals more freedom of choice. Thus, if it has any effect at all, the substitution of bureaucratic by market based instruments should crowd in and not crowd out intrinsic motivation to protect the environment.

4. For a discussion of the relation between ecological and (traditional) environmental economics see, e.g., G. KIRCHGÄSSNER (1997).

5. See, e.g., J. MinSCH et al. (1996, pp. 214ff.)

6. For (first steps towards) a theory of low-cost decisions see G. KIRCHGÄSSNER (1992) as well as G. KIRCHGÄSSNER and W.W. POMMEREHNE (1993). For a more extensive discussion of intrinsic (moral) behaviour in environmental issues see G. KIRCHGÄSSNER (2000).

7. See for this also E. GAWEL (2001). 
(iii) Thus, if market based instruments are not used at all or at least to a much lesser extent than most environmental (and ecological) economists demand, the reason might be that the main actors of environmental policy, especially the bureaucrats in environmental protection agencies and the managers of the industries to be affected have a much stronger interest to apply traditional bureaucratic measures. This is exactly what the Public Choice approach tries to show. And, as it will be demonstrated below, it offers more convincing arguments for the situation of today's environmental policy.

However, while most papers dealing with these problems analyse the past development, they overlook the more recent one. While there is still hardly any use of tradable permits in environmental policy outside the United States, ${ }^{8}$ there has been an increasing number of countries in Europe which use environmental taxes, especially energy taxes. And while several smaller countries (like the Scandinavian countries and the Netherlands) started with this policy, in recent years two major European countries, the United Kingdom and Germany, joined this group. ${ }^{9)}$ Thus, even if the general level is still low, there is much more use today of environmental taxes than at the end of the eighties when R.W. HAHN (1989) wrote his famous paper. ${ }^{10)}$ Moreover, in the Kyoto process, internationally tradable permits were intended to play a major role in international environmental policy, together with other (but related) market based instruments like 'Joint Implementation' and 'Clean Development Mechanism' projects. Thus, on the international level there seems to be an increasing willingness to apply market based instruments. The question is: What has changed since the eighties so that the application of such instruments seems to be more acceptable today than it was in the eighties?

Moreover, a new class of instruments has been introduced which are (at least in the political discourse) often also labelled 'economic instruments': 'voluntary agreements'. They are becoming more and more popular, despite the fact that the empirical evidence of their efficiency is hardly convincing. ${ }^{11)}$ In Switzerland, e.g., they are an integral part of the federal law to reduce $\mathrm{CO}_{2}$-emissions which was passed in 1999.

Thus, while we are still far away from general acceptance and widespread application of market based environmental instruments, the situation has changed at least somewhat, and we must ask whether the old diagnosis given by R.W. HAHN (1989) and the papers in the Public Choice tradition still holds or what the reasons are for the (partly) new development and the wider acceptance of these instruments. To give some answers to these questions is the purpose of this paper. To do so, we first present the main ideas of the Public Choice approach (Section 2). In Section 3 we discuss recent applications of traditional market based instru-

8. For the more recent experience in the United States with such a programme see B. HANSJÜRGENS (1998) or P.L. JoskOW, R. SCHMALENSEE, and E.M. BAILEY (1998).

9. For the more recent experience in the United Kingdom see T. SECOMBE-HETT (2000).

10. There has been, of course, since a long time much use of energy, especially mineral oil taxes in many, especially European countries. These taxes certainly had the ecological impact of reducing energy consumption. However, this was only a positive - and often non-intended - side effect; the reason why these taxes have been introduced and continuously increased is to create public revenue for general and/or for specific traffic purposes like the construction of motorways in Switzerland.

11. See, e.g., K. RENNINGS, K.L. BrockMANN and H. BERGMANN (1997). 
ments, environmental taxes and tradable permits as well as the increasing use of voluntary agreements. Taking all arguments together, we have to conclude in Section 4 that, despite the fact that the use of market based instruments in environmental policy has somewhat increased in recent years, their impact on the actual situation of the environment is still rather modest. If they are employed (or proposed), this is often done for other purposes, and some instruments which are labelled 'market based instruments' are in no way such instruments: the main purpose of their use is to prevent the use of effective instruments of environmental policy. Thus, with some minor revisions, the results of the Public Choice approach still hold, but there is also some hope that the use of incentive oriented instruments in environmental policy will at least somewhat increase in the future.

\section{The Public Choice Approach to Environmental Policy}

The usual way to proceed in the papers which follow the Public Choice approach is to single out the different (groups of) actors which are engaged in environmental policy making and to ask for their interests in the application of the different instruments which could be applied. Following B.S. FREY (1972, pp. 134ff.), typically, four groups of actors are considered: (i) the voters, (ii) the politicians, (iii) the public bureaucrats, and (iv) the 'economy', i.e. the owners, managers and employees of the industries which are to be regulated and their interest groups. In the following, we will give a short characterisation of the main interests of these four groups of actors in environmental policy.

\subsection{The Voters}

Over the last three decades, the sensitivity of voters with respect to environmental issues has certainly increased. ${ }^{12)}$ Thus, the approval of voters of ecologically sustainable policies should become more and more probable. However, it should be taken into account that ecological objectives 'compete' with other interests, especially with 'pure' economic objectives of the voters.

Assuming that the improvement of the environmental quality is a national (or, as in the case of the reduction of $\mathrm{CO}_{2}$-emissions, even an international) public good, the most relevant question regarding the behaviour of voters is: Who will pay the costs? If the price elasticity of demand is low and/or if the supply elasticity is infinitely elastic, as in the case of mineral oil prices in small countries, where the consumer price of these products is determined by the prices on the international spot markets, ${ }^{13)}$ the consumers have to bear the costs. This implies that the majority of voters directly pays for such a policy. But if price elasticity is high, only a small part of the burden of an environmental measure which increases the production costs of a good can be passed on to the consumers. Thus, the producers, shareholders, managers as

12. See, e.g., the results of the IMAS-surveys for Austria (IMAS $(1995,1996))$ or the results for Germany presented in J. HORBACH (1992).

13. See, e.g., G. KIRCHGÄSSNER and K. KÜBLER (1992) for Germany and G. KIRCHGÄSSNER (1994) for Switzerland. 
well as workers of these firms, have to bear the costs. Consequently, the resistance to environmental programs might be higher in regions with a high share of producer interests which oppose such a policy, because a higher burden can lead to reduced profits, wages and employment in these regions.

In Germany, empirical evidence for such a trade-off between the reduction of unemployment and ecological objectives was found. J. HORBACH (1992) shows that in regions with a high unemployment rate the Green Party receives fewer votes in elections than in other regions. Moreover, he also shows that the more important the chemical and steel industries are in a certain region, the worse the election chances are for this party, because its ecologically oriented economic policy program might weaken the position of these industries. Thus, citizens voting out of self-interest might be an obstacle for the approval of any kind of environmental policy. This implies that too little might be done, especially in those regions where environmental policy is needed most.

New arguments have emerged in the recent international discussion of the double dividend. The implementation of incentive oriented environmental tax policies need not be accompanied by an increase of the tax burden but can also be realised through a shift in the tax burden. In such a case there is no immediate trade-off between fighting unemployment and enforcing stricter environmental policies. On the contrary, many simulations show that it might even be possible to have a small gain in employment. ${ }^{14)}$ As a study of the OECD (1997) shows, a large number of winners among different economic sectors and firms might be generated, but with only small gains. On the other hand, there would be a few distinct losers among the firms whose economic position could deteriorate quite substantially. Thus, at first sight, politicians might be expected to enact such a tax alternative in response to the preferences of the majority of voters instead of caring for the minority of losers. However, as Public Choice theory tells us, “ ... a small concentrated identifiable, and intensely interested pressure group may exert more influence on political choice making than the much larger majority of persons, each of whom might expect to secure benefits in the second order of smalls ..." ${ }^{\text {15) }}$ Thus, even if a double dividend allows to fight unemployment by enforcing stricter environmental policies in the economy as a whole there still can exist a political trade-off between fighting of unemployment in small, intensely interested, and highly influential pressure groups of potential losers and an incentive based environmental policy. ${ }^{16)}$

However, the case of a double dividend where employment is rising with a stricter environmental policy is an exception in environmental policy making, which to a large extent depends on the existence of involuntary unemployment. ${ }^{17)}$ In most situations there is a trade-off

14. See, e.g., the review of such studies in G. KIRCHGÄSSNER (1998, 1999), or F. SCHNEIDER (1998) with results for Austria, G. KIRCHGÄSSNER, U. MÜLLER and M.R. SAVIOZ (1998) with results for Switzerland or CH.M. SCHOLZ (2000) and S. BACH et al. (2001) with results for Germany.

15. J.M. BUCHANAN and G. TUlLOCK (1975, p. 142).

16. This does not only hold in representative democracies but also in direct democratic systems, as the referendum in Switzerland on September 24, 2000, shows, when such a reform was rejected by the voters with a majority of 54 percent. At this occasion, the potentially losing industries invested quite a lot of money into their campaign.

17. See, the corresponding simulation results in G. KIRCHGÄSSNER, U. MÜLLER and M.R. SAVIOZ (1998). 
between the production of better environmental quality and the production of consumer goods, i.e. the voters have to make a choice between better environmental quality and higher real income. In such situations, the decision of voters depends on the information of the citizens about the consequences of environmental problems, the lag between the time when the policy measure is taken and the time when the environmental situation improves, and the discount rate of voters. Especially with respect to measures which are mainly to the benefit of future generations, self-interested individuals would generally not be willing to bear high costs. This is one of the main obstacles against efficient $\mathrm{CO}_{2}$-reduction policies. But similar conditions hold in other areas of environmental policymaking as well. Consequently, it can be expected that in many cases voters care more about the economic short-term development than about the environmental situation. This might delay or even prevent the approval of ecologically-oriented politics by the majority of voters. Even if a citizen is to some extent altruistic, well-educated and -informed it is not obvious that she/he as a 'rational' (even longterm oriented) voter will support ecologically oriented economic policies in elections or referenda. $^{18)}$

This can lead to an undersupply of such policies. It should, however, not lead to the introduction of inefficient environmental policies. Thus, it is difficult to explain why voters should be in favour of command and control instead of market oriented environmental policies. Nevertheless, voters seem to prefer a policy of regulations and prohibitions. One of the reasons for this could be that the costs of the traditional policy are less visible than the costs of market oriented policies. Insofar, there might be a kind of cost-illusion, i.e. voters may have the impression that an improvement of the environment could be reached by means of regulations and prohibitions without costs, i.e. without reducing the income of the average citizen. However, this argument is strikingly at odds which the assumption of rational expectations which is usually used in Economics (and Public Choice theory as well) and which is assumed to hold at least in the long-run. Moreover, if voters behave rationally, political entrepreneurs should be able to overcome this illusion. Thus, voters might be (partly) responsible for the undersupply of environmental policies, but they can hardly be held responsible for the lack of market oriented measures in this policy.

\subsection{The Politicians}

Politicians can be assumed to pursue a certain policy if - given that they achieve their objective - it is supported by a majority of voters, under the qualification that there is no considerable resistance from neither the bureaucracy nor the interest groups. Insofar, if voters accept or even demand an undersupply of environmental policies, a government which wants to maximise its re-election probability gets no incentive from the voters to provide a better environmental quality.

However, even a democratic government is hardly ever only seeking re-election. According to the partisan hypothesis first developed by D. HIBBS (1977; see also 1992) and incorporated

18. The role of altruistic/moral behaviour in such decisions is discussed in G. KIRCHGÄSSNER (2000). 
into the politico-economic models of B.S. FREY and F. SCHNEIDER (1978, 1978a, 1979) reelection is more of a constraint which the government has to respect than an objective in itself. Thus, if a coalition government includes a 'green' party and/or if the dominating party of the government has a clientele which has an especially strong environmental orientation a government might provide a stronger environmental policy than it is demanded by the voters altogether (the median voter) as long as this does not endanger its re-election prospects. ${ }^{19)}$ On the other hand, if the clientele of the government is more economically oriented it will hardly accept that the output of consumer goods is reduced in order to improve environmental quality. Thus, there might be a less strict environmental policy than it is demanded by the median voter.

Even if the level of environmental activities is (on the average) too low, the question again arises whether the remaining policies in this field are carried out in an efficient way. If there is no pressure by the voters but if they are, instead, in favour of more visible but less efficient policies, the use of bureaucratic instruments might be more in the interest of politicians than the use of economic instruments. However, there are two qualifications to be made. First, because the government should be better informed than the average voter, it should take into account that the higher efficiency of an environmental policy which uses economic instruments allows to use resources for other purposes and - in this way - to satisfy more of the demands of the own clientele and/or to improve the re-election prospects. For this reason, the government should - ceteris paribus - be more in favour of applying economic instruments than the average voter.

Second, environmental taxes might have a special attraction for governments because they create revenue which can be used to cut other taxes and/or to finance additional projects. This can be advantageous for the government if the tax resistance against 'green taxes' can be expected to be lower than against other taxes. This holds especially if the clientele of the government is more environmentally oriented than the average voter. ${ }^{20)}$ On the other hand, as the opposition will try to use its chance and to make strong opposition against introducing or raising such visible taxes the leeway of a government to pursue such a policy is limited.

It is, moreover, possible to present environmental taxes as acceptable measures to the voters, if these taxes are characterised as 'punishment' for polluting the environment and if they are applied mainly to industrial polluters. Politically, it might be more difficult to sell the creation of a market for tradable permits to the voters because these can be considered as 'licences to

19. In the typical European political system where the government is elected by a majority of the parliament the parliamentarians have nearly the same interests as the government. Thus, we only discuss the role of the government. This situation is different in the U.S. where the election of the government is independent from the elections of the members of the congress and in Switzerland where - according to the system of half-direct democracy on the federal level - the government is actually quite independent from the parliament. In both countries, each single member of the parliament has much more independence from the official line of their party than their colleagues in the representative systems of the other European democracies. Consequently, they are closer connected to the citizens of their constituencies and, therefore, there is also much wider variation in the environmental policy they favour.

20. Acknowledging this, several opponents against the introduction of environmental taxes do not really argue against the use of environmental taxes per se but they are anxious that, given the less severe tax resistance, the government might be successful in increasing the total tax load. See, e.g., K.W. ZIMMERMANN (1996). 
pollute the environment' which - from a moral point of view - might be seen as morally unsound by those people who are especially strongly engaged for the natural environment. ${ }^{21)}$ Moreover, at least as long as grandfathering is used as the method for the original distribution of the emission rights, the government is much less interested in using tradable permits than in using ecological taxes.

Taking all these arguments together, the interests of the government might in the average lead to a less than optimal level of environmental policy, but - as with the voters - they can hardly be the reason why the use of market oriented environmental instruments was on such a low level in the past. Therefore, those who really oppose such a policy must be the public bureaucracy and/or private business, i.e. the regulated industries and their interest groups.

\subsection{The Regulated Industries and Their Interest Groups}

Officially, representatives of the industries which are to be regulated by environmental policy are much in favour of economic instruments. But whenever the application of such instruments is discussed, they are at least very hesitant and in most cases in strong opposition to such a policy. If, e.g., ecological taxes are discussed, they argue against it and instead favour voluntary agreements which, as will be shown below, are just the opposite of an economic instrument of environmental policy, command and control policies or - at the most - tradable permits. ${ }^{22)}$ For the latter, however, they demand grandfathering of the original distribution of the emission rights. Thus, if there are any economic instruments used at all, besides subsidies which are not discussed here, the regulated industries prefer tradable permits which are distributed by grandfathering. In any case, they prefer a policy of command and control to a policy applying ecological taxes. ${ }^{23)}$

But why should the polluters, especially the industrial polluters, oppose the use of market oriented environmental policy instruments? After all, using these instruments the same ecological impact could be reached 'more cheaply' i.e. at lower costs, which finally should be in the interest of the relevant industrial sectors as well. It is obvious that the profit interest of any single producer which has a relevant amount of emissions is against any environmental regulation because it reduces its expected profits. But why is there a quite special opposition against economic measures of environmental policy?

The two main reasons for this opposition are probably the high efficiency of such a policy and distributional questions.

21. For a discussion of ethical aspects of international emissions trading see H.E. OTT and W. SACHS (2000).

22. See J. HoRBACH (1992) who shows that two thirds of the German companies favour standards whereas only one third favours levies and taxes.

23. There are some producer organisations which are in favour of environmental policy and which support the use of environmental taxes, like the ÖBU (Swiss Association for Environmentally Conscious Management; Schweizerische Vereinigung für ökologisch bewusste Unternehmensführung) in Switzerland. However, the members of these associations are often companies which have only few emissions and which are, therefore, affected by environmental policy only to a small extent. 
(i) At the level of the economy as a whole, the high efficiency of economic instruments means that the aspired ecological objectives can be reached with minimal (social) costs. For the single firm, however, the situation is quite different. As long as a policy of command and control is pursued, it has a (sometimes considerable) leeway for negotiations with its environmental protection agency. In these negotiations it has an informational advantage; it knows the processes and the potential costs if the emissions have to be reduced by a certain amount, and it can threat with a reduction of employment or even with the displacement of the firm if the regulations are too strict. On the other hand, if environmental taxes are used, the firm can pollute as much as it wants, but it has to pay for it. Reductions of a tariff which has been fixed in the parliament and written into a law are much more difficult to negotiate than the extent of a regulation which is necessarily more or less - individual for each firm. Thus, it can be expected that the regulation will on the average - be less strict with a command and control policy than if economic instruments of environmental policy are used.

(ii) There are also, however, important distributional consequences. Let us assume that the firm uses the same technology and has the same emission in both regimes, under a command and control and under an economically oriented environmental policy. Thus, at the margin everything is the same, the same technology, the same marginal costs, and the same prices of the goods produced. Moreover, the costs for reducing the emissions are the same. Inframarginally however, if taxes or tradable permits are used the firm has to pay for its emissions while under a policy of command and control it gets them for free. Thus, to the extent of the legal emissions it gets an additional rent. ${ }^{24)}$ If wages are given, this rent can be appropriated by the owners. However, the employees (and/or their organisations, the trade unions) will realise that there is a possibility for a wage increase; they will demand their share of this rent. On the other hand, if taxes are used (and the revenue is used to cut other taxes, e.g.,) the general public benefits. Thus, shareholders (employers) as well as employees have an own interest to prevent the use of economic instruments.

A similar argument holds if we compare grandfathering with auctioning tradable permits. If there is competition, at the margin both systems lead to the same condition. That implies that the prices for the goods produced will be the same. If the permits are auctioned, there is an additional revenue for the government which can be used to cut other taxes and which - in this way - may be to the benefit of the general public. If grandfathering is used, however, as, e.g., in the case of the sulfur dioxide allowance-trading program in the United States, ${ }^{25)}$ the existing firms get an additional rent. Moreover, they get a competitive advantage against newcomers in the market who do not get this rent because they have to pay for all the permits they need: grandfathering of pollution rights creates a bar-

24. This argument has first been put forward by J.M. BUCHANAN and G. TULLOCK (1975).

25. See P.L. Joskow, R. Schmalensee, and E.M. BAILey (1998, P. 671): “Allowances are given to existing electric generation units and those under construction, according to fairly complicated rules ... . For our purposes here it suffices to note that essentially all of the allowances were allocated 'free' to incumbent sources." A more detailed description if the initial allocation is given can be found in P.L. JOSKOW and R. SCHMALENSEE (1998). 
rier to entry against new firms. Thus, it is no surprise that the existing companies as well as their interest groups favour the grandfathering of tradable permits. ${ }^{26}$ )

Given this situation and the at least partial conformity of employer and employees interest it is no surprise that the industries which are to be regulated generally oppose the use of economic environmental instruments, especially of ecological taxes. ${ }^{27)}$ Moreover, their organisations are well organised and they are important players in the political game. There are five main reasons why these interest groups are not only better organised than environmental interest groups but also better suited to achieve their self-interested goals:

(i) In contrast to environmental interest groups, the respective industry and business associations usually have sufficient financial backing which is used for efficient lobbying.

(ii) Producers themselves are closest to the origins of environmental problems in the production sector. This is the reason for substantial information asymmetries. Therefore, 'green' groups often have difficulties in getting information about pollution effects as well as about the feasibility of alternative technologies.

(iii) Based on this information asymmetry, industry and business associations often have considerable influence on public opinion through their publications as well as through their impact on the media.

(iv) The 'market power' of these interest groups is a crucial factor in the achievement of their objectives in the political arena. It is not only important in the goods and services markets but in the labour market as well, especially in the form of the threat of transferring production abroad.

(v) Quite often these associations gain personal representation in legislative institutions, in the parliament and its committees, which makes it possible to postpone or even reject environmental issues.

Taken together, representatives of industrial and business interest groups are able to influence legislative proposals in their early stages through active lobbying in hearings and in parliamentary committees. For that purpose, they provide detailed information about environmental measures. This has the effect of linking together lobbyists and members of the legislative bodies. As a result of this relationship, arrangements are made between the political administrative system and 'private' interest groups representing business interests. In Germany, such agreements have become common practice in more than 50 industrial committees and "voluntary self-obligations' as well as in several hundred committees for the definition of the 'best available technology'. ${ }^{28)}$

26. See for this also G.T. SVENDSEN (1999).

27. There seems to have been some change of the opinion in the United States. According to G.T. SVENDSEN (1999), private business interest groups are today more in favour of a grandfathered permit market, and no longer so much in favour of a command and control policy, but they still reject a tax policy.

28. See G. MAIER-Rigaud (1996) or J. Helbig and J. VolKert (1999). 
Compared to their counterparts of business and the economy, environmentally oriented interest groups are in a weak position. They have the possibility of organising spectacular actions, a strategy which is often used by Greenpeace which might be the best known of these groups. In doing so, in special situations they can have a strong impact on public opinion, influence private consumption and in this way influence the policy of single companies, ${ }^{29)}$ they might also have some impact on the decisions of voters, but they rarely have the same direct impact on the parliamentary system and the public bureaucracy economic interest groups have. Moreover, until the eighties the green interest groups where themselves in favour of command and control measures in environmental policy and against the use of economic instruments. Their main argument was the one stated in the introduction that the natural environment should not be 'commercialised'. Against the combined pressure of economic and environmental interest groups, however, an efficient environmental policy using economic instruments had no chance at all.

\subsection{The Public Bureaucracy}

Already a cursory view at the available evidence tells us that - at least in Europe - many members of the public environmental bureaucracy are in strong opposition against the application of market based instruments of environmental policy. They rather prefer the use of command and control. In most cases they favour, of course, policies which improve the situation of the natural environment; most members of the 'green bureaucracies' are highly motivated to pursue this goal. ${ }^{30)}$ However, they do not necessarily favour efficient policies. More important for them is that a policy strengthens their personal position in the environmental policy game.

The empirical studies by K. HolzINGER (1987) demonstrate that German environmental administrations have at least some leeway to follow their own interests, whereas objectives such as 'economic efficiency' or 'overall economic cost optimisation' are only of minor importance for them. They are vitally interested in environmentally policy measures which are labour- and resource-intensive. As a result - and in accordance with the economic theory of bureaucracy as originally developed by W.A. NISKANEN $(1968,1971)$ - they are able to increase their number of employees, and each year to have a larger budget at their disposal. The result of this is that the environmental administrations will try to implement those environmental policy measures which require high administrative controls. To increase their leeway they want the political authorities to regulate as little as possible so that they have the greatest possible leeway (and budget) for their own decisions. ${ }^{31)}$ Discretionary budgets are also necessary in order to meet the demands of those lobbies for which the different environmental sections of German ministries have become even more important than the parliament with its committees.

29. The best known case is that in 1995 Greenpeace succeeded in preventing Shell from sinking the oil platform Brent Spar into the North See. See for this M. HuXHAM und D. SuMnER (1999).

30. For a model which employs this assumption to explain the results of international climate protection policy see R.D. CONGLETON (1995).

31. See the results of the surveys described in E. GAWEL (1994a, 1995). 
Economic instruments and especially environmental taxes are much less attractive for the public bureaucracy. While command and control policies can only exist with high labour costs and other expenditures, the use of taxes requires much less expenditure and less staff. Hence, a budget increase or a rise in the importance of environmental authorities is less likely than with the use of standards. Furthermore, a change from the current system of environmental standards to a system of taxes would require a high degree of flexibility in the environmental agencies.

Using taxes or tradable permits would of course reduce the information requirements of the public environmental bureaucracy considerably. Detailed information is only necessary for the tolerable total burden, for the 'correct' total emission amount derived from it, and - in the case of taxes - on the reactions of the industries to the taxes, which can be obtained in a kind of trial-and-error procedure by a gradual increase of the tax rate over a longer time span, but no detailed information about the prevention costs of different producers is needed, which is difficult to acquire. Thus, the efficiency of the bureaucracy could be increased considerably. But this is not necessarily also in the interest of the members of the bureaucracy, as the lower information requirements make it rather difficult to justify a large budget and a large staff.

Taking all arguments together, the industries which are to be regulated and the members of the environmental bureaucracy are the ones who are most in favour of command and control policies, and both have a strong impact on the design of the actual policy. Thus, it comes as no surprise that economic instruments like environmental taxes or tradable permits were hardly used up to now. On the other hand, with respect to the extent of the environmental program the interest of these two groups of actors are quite opposite: While the bureaucrats favour a strict, most industries strive for a rather soft environmental policy. Thus, whether a policy is really strict or not depends mainly on the preferences of the voters (and of the clientele of the party (parties) in government). Taking into account the discounting behaviour of voters, the policy might be strict in those areas which already today have a direct, noticeable impact, but rather loose in those areas which would mainly benefit future generations. And this is exactly what we observe. There have been, e.g., considerable improvements in the water quality of our lakes and rivers, but up to today there is hardly any effective policy to prevent or even slow down global warming.

\section{The Recent Use of New Instruments}

As already mentioned in the introduction, the situation has somewhat changed in the last ten years. In the U.S. the use of tradable permits has increased, some European countries have taken steps towards 'greening' the tax system, in the Kyoto protocol the international use of tradable permits to reduce $\mathrm{CO}_{2}$-emmissions has been negotiated, and there is an increasing use of voluntary agreements. Thus, it appears as if the resistance against market based environmental instruments could be overcome, even if this takes a long time. But before one is too optimistic about this, one should analyse these developments more carefully. This is done in the following, using again the Public Choice approach. Consequently, many arguments which have been mentioned above will be used again. 


\subsection{The Ecological Tax Reforms}

The main theoretical as well as empirical argument in favour of an ecological tax reform is the hope for a double dividend: If taxes which cause distortions in one sector of the economy are reduced and at the same time taxes which reduce distortions in another sector of the economy are introduced instead, the efficiency of the whole economy should improve and - as a consequence - unemployment should be reduced. This idea, originally proposed by $\mathrm{H}$. $\mathrm{CH}$. BINSWANGER et al. (1983) and strongly supported by D.A. PEARCE (1991) could play a key role in reducing $\mathrm{CO}_{2}$-emissions by the introduction of a general energy and/or $\mathrm{CO}_{2}$ tax and on this way - in fighting global warming. In the last decade, it has become more and more popular in Europe, but not so much because of its environmental consequences but mainly because it seems to be an ideal method to solve the problems of many European labour markets without, e.g., having to introduce more flexibility into these markets. This belief is quite widespread despite the fact that the scientific discussion starting with A.L. BovENBERG and R.A. DE MoOIJ (1994) has shown that with such a reform an increase of employment while not impossible is difficult to accieve, and that it might improve the labour market situation somewhat, but not really solve the unemployment problem. ${ }^{32)}$ Thus, in many countries not only green but also other left-wing parties are today in favour of such a policy, and it is also supported by trade unions. This is insofar no surprise as there is quite a lot of evidence that left-wing parties are more active in fighting unemployment compared with right-wing parties which are more concerned about inflation. ${ }^{33)}$ Thus, the main interest in pursuing such a policy by left-wing (or green) parties is in many cases not a concern about the situation of the natural environment but about the labour market, even if the expectation is that it will help the environment more than the labour market: Such governments might help the environment 'for the wrong reason'.

On the other hand, as already mentioned above, environmental taxes have a special attraction for left-wing parties which traditionally aim for a higher government (tax) share because these taxes creates revenue, which can be used to finance other projects, and the tax resistance against 'green taxes' might be lower than against other taxes. ${ }^{34)}$ This is important in a situation where the current social security system and its financing is not at all sustainable and besides structural changes - new sources have to be found to finance it. Again, such governments might help the environment 'for the wrong reason'.

But such a policy is strongly opposed by important interest groups from the energy intensive industries which have to lose quite a lot by such a reform. And, as stated above, such interest groups are very influential in the political process. In Switzerland, e.g., they successfully organised a referendum against such a reform and spent quite a lot of money in the campaign.

32. See, e.g., the surveys in L.H. GouldER (1995), G. KIRCHGÄSSNER (1998) and A.L. BovenBERG (1999), but also the simulation studies mentioned in footnote 11 above. - This is, of course, no argument against such a reform which still can make much sense; it is an argument against expectations of some of its proponents which are too high and which - with high probability - will prove to be wrong.

33. See, e.g., D.A. HIBBS $(1977,1992)$ as well as the politico-economic models of B.S. FREY and F. SCHNEIDER (1978, 1978a, 1979) and the survey about political business cycles by M. PALDAM (1997).

34. For the discussion of this argument see, e.g., K.W. ZIMMERMANN (1996) or F. SCHNEIDER (1998). 
This certainly had an impact on the voters: On September 24, 2000, the reform was rejected by the Swiss electorate by a majority of 55 percent. In other countries where there is no possibility of a referendum against such a policy they were at least insofar successful that exceptions were made for the most energy intensive producing industries or even for the whole production sector, i.e. in the latter case only consumers have to pay these taxes. ${ }^{35)}$ This implies that especially those producers are exempted who produce most $\mathrm{CO}_{2}$-emissions which strongly reduces the environmental impact of this policy.

Thus, while these reforms might be seen as a step in the right direction, taking into account the motives of the politicians for enforcing such a reform one has to conclude that this new development is far away from indicating a change in the general perception about the relative merits of command and control versus economic instruments of environmental policy and of the political acceptance of the latter. We still have the situation that - in principle - nearly everybody supports the use of economic instruments, but when it comes to their application there is very strong resistance by important political actors. At best, they will be introduced for other (non-environmental) reasons and/or in a way which is not very helpful for the environment. But, on the other hand, it is a step in this direction and one might hope that over time citizens become more familiar with such instruments and their advantages which might - in the long-run - increase their acceptance in the electorate.

\subsection{The Use of Tradable Permits in International Climate Policy}

One might argue that there is at least a change on the international level. In the Kyoto process, internationally tradable permits were intended to play a major role in international environmental policy, together with other (but related) market based instruments like 'Joint Implementation' and 'Clean Development Mechanism' projects. Thus, there seems to be an increasing willingness to apply market based instruments. This has been forced by the United States which - up to now - is the only country where tradable permits play a major role.

At a first glance, this seems to be an excellent idea. Global warming is a true global public good, and the damage caused by $\mathrm{CO}_{2}$-emissions is independent of the location of the emitting source. Thus, $\mathrm{CO}_{2}$-permits which would ensure that the price for an emitted unit is the same all over the world are the economically most effective instrument to cope with this problem. Moreover, as, e.g., CH. BÖHRINGER and H. WELSCH (1999) show, the use of internationally tradable $\mathrm{CO}_{2}$-emissions permits could effectively reduce the costs of a severe reduction of these emissions. But the main question is how to allocate the $\mathrm{CO}_{2}$-emission rights before the trading starts? The natural way would be to distribute them per capita: each human being has the same right to pollute the atmosphere. This would, however, result in a huge redistribution from the North to the South. From a social point of view this might be acceptable, but it is bare of any realism to assume that the industrial countries, especially the United States, would ever accept such a redistribution, because this would lead to a tremendous loss of real income. The alternative is 'grandfathering' to nations, where at the starting point every country gets

35. For an overview of the different regulations see, e.g., A. MAIER ZU HIMMERN and G. KIRCHGÄSSNER (1995). 
pollution rights according to its actual pollution. But this is totally unacceptable for the developing countries; it would largely impede their development opportunities. Moreover, an international institution (like a stock exchange) is missing which not only organises the trade but, what is much more important, also has the power to enforce that $\mathrm{CO}_{2}$ is only emitted by a country if it owns the necessary permits.

Thus, we are far away from solving the global warming problem with tradable permits. The pressure of the United States to introduce such mechanisms might have been of a more symbolic nature: they demanded to introduce an instrument of which they knew that, because of the distributional problem, there is no real political chance at all to implement it. What can be done at best at the moment is an international agreement like the Kyoto protocol where the industrialised countries constrain themselves to reduce their $\mathrm{CO}_{2}$-emissions and the developing countries are allowed to somewhat increase them. If this is agreed on, tradable permits might play a secondary though not unimportant role. But even this approach has now been rejected by the Bush-administration: At the moment the U.S. government is not willing to accept any reduction of its own $\mathrm{CO}_{2}$-emissions; on the contrary: its energy plans intend to increase the burning of fossil fuels in the next years.

Moreover, to have a real effect the reductions in the industrial countries will have to be much larger than those negotiated in the Kyoto protocol. How the different countries manage to reduce their emissions might be up to them. Joint implementation or clean development mechanism projects might be of some help for some countries, but they can hardly be the solution of the problem, because the main reductions must take place within and not outside the industrial world.

Again, the introduction of tradable permits - if it ever happens - might be seen as a step in the right direction, and one might hope that over time citizens (and countries) become more familiar with such instruments and their advantages, and this might - in the long-run - increase their general acceptance. In the European countries there are still very few applications of this instrument. In Switzerland, e.g., there is only one case, in the cantons Basel-Stadt and BaselLandschaft, where a system of tradable permits has been introduced. However, this was a complete failure, despite its theoretical possibility no trade took place at all. ${ }^{36)}$ The main reason was that the conditions under which the trading should take place were very restrictive; in addition the firms might have had not enough trust in this system (or in the politicians or bureaucrats managing this system, respectively). In such situations, the use of tradable permits at the international level might improve the chances for their acceptance at the national level. But at the moment, it is still open whether these instruments will ever be applied at a large scale at the international level at all.

\subsection{The Use of Voluntary Agreements}

Even when the development with respect to ecological taxes and tradable permits is taken into account there is not very much use of these market-based environmental policy instruments

36. See E. Staehelin-WitT and A. Spillmann (1994). 
today. On the other hand, there is an increasing use of 'voluntary agreements' which are often in the political discourse and in the popular press but sometimes even in the academic literature $^{37)}$ also are labelled as 'economic instruments'. ${ }^{38)}$ Is this another possibility to introduce more market mechanisms into environmental policy?

A closer look at this instrument shows, however, that this is definitely not the case. Voluntary agreements are typically agreed on if there is a threat that otherwise the government would use other, especially command and control measures. They are not 'voluntary' in the real sense of this word, but an attempt to evade stricter environmental measures. ${ }^{39)}$ This holds the more if the government dispenses with its other instruments, typically one of its bureaucratic measures. The advantage of these agreements is that they give more leeway to the single firms in reaching the environmental objective, because they usually only fix a limit for the emissions which has to be reached at a certain point of time. But the same leeway can be given to a firm if not a voluntary agreement but a binding standard is used instead which has to be fulfilled at a particular date. Moreover, because a voluntary agreement is no more than a (voluntary) 'declaration of intent' which is typically not given by the representatives of single firms but by their interest groups, it is in no way an effective constraint for the single firms. Thus, the government has no possibility to enforce it if it is violated. In this situation it can, of course, use some of its traditional instruments, but then this comes with a considerable delay and possibly with a further deterioration of the situation of the natural environment. The only possibility to make voluntary agreements effective is to combine them from the beginning with the threat that the government will intervene if the negotiated results will not be reached. But in this case the voluntary agreement is actually superfluous; it is just a kind of symbolic policy.

One might argue that this kind of symbolic policy might, nevertheless, improve the situation of the environment at least somewhat because there is an additional motivation for the managers of the firm which are responsible for its environmental performance to improve it. Such an argument is in accordance with the behavioural theory of the law which states that even mild laws, i.e. laws with low sanctions, motivate people to obey a law, even if pure self-interest would tell them to violate it. ${ }^{40)}$ J.-R. TYRAN and L.P. FELD (2001) present some experimental evidence which makes the interpretation possible that this effect is especially strong if people can themselves decide whether such a law should be introduced or not. In the case of voluntary agreements such a situation is given.

The available empirical evidence shows, however, that with a voluntary agreements generally firms do not follow a stricter policy than they had done without it. ${ }^{41)}$ A significant impact of the agreement is hardly ever observed. This is, however, not astonishing as such 'weak incen-

37. See, e.g., T. SECOMBE-HETT (2000, p. 105).

38. The rhetoric used is that they are market based instruments because they are voluntary in the same way as market transactions are voluntary.

39. For a theoretical analysis of voluntary agreements see, e.g., K. CONRAD (1998).

40. See, e.g., T.R. TYLOR (1990) or R.D. COOTER (1998).

41. See for this K. RENNings, K.L. BrockMANN and H. BERGMANN (1997). 
tives' are mainly effective in 'low-cost situations, ${ }^{42)}$ and the typical production decision in a firm does not fall into this category. Moreover, if there is strong competition on a market a firm can hardly afford to implement costly measures to reduce the emissions if their competitors do not also have to do so. In such a prisoner's dilemma situation it is completely rational for a firm despite of the existence of such an agreement not to do more than they had done otherwise as well. Only the rhetoric might change somewhat. And the leaders of the interest groups who negotiate such an agreement will have a strong incentive to bargain for the lowest possible level of environmental measures and to accept not more than their member firms would have done in any case, not only because it saves costs to them but also because this increases the possibility that the firms can reach the negotiated standard and that afterwards this agreement can be sold to the public as a success. This can help to prevent the government from applying strict environmental policy measures in the future as well.

That voluntary agreements can be seen as a kind of symbolic policy shows the Swiss experience with the $\mathrm{CO}_{2}$-law which combines such agreements with a tax for the case that the environmental objective given for the year 2004 is missed. The first draft of this law made by the government in 1997 intended to give the government the right to introduce these taxes. However, the parliament changed this part; the carbon tax can only be introduced by a decision of the parliament. Today, it is quite obvious that the objective will not be reached. And already now the right-wing Swiss People Party (SVP) demands that no tax will be levied even if the environmental objective is largely missed. Thus, this law, which is then reduced to a voluntary agreement, will have hardly any real effect. Its existence helped, however, to organise the campaign in 2000 against the introduction of a first step of an ecological tax reform. In this campaign it was argued that the $\mathrm{CO}_{2}$-law was the correct and sufficient instrument to reach the environmental objective, making an ecological tax reform allegedly superfluous. Thus, from an ecological point of view the passing of the $\mathrm{CO}_{2}$-law might even prove to have been counterproductive.

\section{Concluding Remarks}

Why did the patient not followed the doctor's orders?, was the basic question of R.W. HAHN's (1989) seminal paper, and it is still the question this paper tries to answer. In the last twelve years, the situation has changed somewhat insofar as inside the United States there has been a increasing use of tradable permits while in Europe environmental taxes, especially energy taxes became more popular. Thus, the use of economic instruments has somewhat increased, but its use in Europe occurred at least partly for the wrong reasons: to create additional revenue was one of the main reasons to introduce and/or increase energy taxes.

From the point of view of protecting the environment, this does not have to be considered as only negative. The most important ecological taxes in Europe are taxes on gasoline which are much higher compared to the U.S. This is probably the main reason why European automobiles need much less petrol than those produced in (and mainly for) the United States. In

42. See for this, e.g., G. KIRCHGÄSSNER (1992, 2000). 
Europe, these taxes have a long tradition, but 15 years ago their existence has hardly ever been justified with environmental reasons. This has changed, of course, because today the main reasons why an increase of these taxes is demanded (especially by green groups and parties) are ecological ones. But - according to the arguments given above - one should carefully distinguish between the political rhetorics and the true reasons. In Germany, e.g., the conservative government at the beginning of the nineties drastically increased mineral oil taxes in order to generate additional revenue to finance the German unification. ${ }^{43)}$ And in Switzerland, where the people accepted and increase of the mineral oil tax by $0.22 \mathrm{SFr}$ in a referendum in March 1993, one of the official reasons was to improve the situation of the environment, but the main reason was to generate additional revenue to finance the construction of additional motorways. But whatever the 'true' reasons were, these tax increases definitely had a positive effect on the environment as well.

The small increase in the use of economic instruments of environmental policy does not invalidate the arguments of the Public Choice approach why there is such little use of these instruments. As already stated by J.M. BuCHANAN and G. TULlock (1975), command and control are still preferred to market based instruments by the main actors in the environmental policy game, private business (and their interest groups) and public bureaucrats. The only novelty is that, as has been shown by G.T. SVENDSEN (1999), in the U.S. there has been some change of the opinion towards the use of grandfathered tradable permits. The same development might - with some delay - also happen in Europe. We might come into a situation where governments are favouring additional taxes while private business, in order to avoid these taxes, favour grandfathered tradable permits. Thus, even though there has been little use of these instruments in the past, there might be some increase in the future. And, while in the past most environmental economists gave environmental taxes better chances than tradable permits, because the 'licences to pollute' might evoke moral objections, the opposite development can occur: tradable permits might be also used in Europe at the national level and, depending on the further development of the Kyoto process, at the international level, too. Thus, the future of market based instruments of environmental policy does still not look bright, but at least somewhat brighter than 12 years ago when R.W. HAHN (1989) published his seminal paper.

43. Between 1989 and 1995 mineral oil taxes (excluding the value added tax) increased from 0.651 DM per litre to $1.080 \mathrm{DM}$ per litre. This is considerably more than the increase of $0.18 \mathrm{DM}$ by the ecological tax reform of the new government since 1998. 


\section{References:}

S. Bach, M. Kohlhatas, B. Meier, B. Praetorius and H. Welsch (2001), Auswirkungen und Perspektiven einer ökologischen Steuerreform in Deutschland: Eine modellgestützte Analyse, mimeo, University of Osnabrück, April 2001.

W.J. BAumol and W.E. OAtes (1971) The Use of Standards and Prices for Protection of the Environment, Swedish Journal of Economics 73 (1971), pp. 42 - 54.

H. Ch. Binswanger, H. Frisch, H.G. NutZinger et al. (1983), Arbeit ohne Umweltzerstörung, Fischer, Frankfurt, $2^{\text {nd }}$ edition 1988.

CH. BÖHRINGER and H. WeLSCH (1999), C\&C - Contraction and Convergence of Carbon Emissions: The Economic Implications of Permit Trading, Centre for European Economic Research, Discussion Paper No. 99-13, Mannheim, 1999.

A.L. BovenBerg (1999), Green Tax reforms and the Double Dividend, International Tax and Public Finance 6 (1999), pp. 421 - 443.

A.L. Bovenberg and R.A. DE Mooij (1994), Environmental Levies and Distortionary Taxation, American Economic Review 84 (1994), pp. 1085 - 1089.

J.M. BuchanAn and G. TUllock (1975), Polluters' Profits and Political response: Direct Controls Versus Taxes, American Economic Review 65 (1975), pp. 139 - 147.

R.D. Congleton (1995), Return to Rio: On the Political Economy of Environmental Treaties, Universität Konstanz, Sonderforschungsbereich "Internationalisierung der Wirtschaft", Diskussionsbeitrag Nr. 280, Serie II, September 1995.

K. CONRAD (1998), Voluntary Environmental Agreements, Emission Taxes and International Trade: The Importance of Timing of Strategies, mimeo, University of Mannheim, 1998.

R.D. COOTER (1998), Expressive Law and Economics, Journal of Legal Studies 27 (1998), pp. 585 608.

B. DijKstRA and A. NentJes (1994), A Political Economy Approach to Instrument Choice in Environmental Policy, Paper presented at the Meeting of the European Public Choice Society, Valencia, April 6-9, 1994.

P.B. DownIng (1991), A Political Economy Model of Implementing Pollution Laws, Journal of Environmental Economics and Management 8 (1991), pp. 255 - 271.

A. ENDRES and M. FINUS (2000), Warum haben marktwirtschaftliche Instrumente im internationalen Umweltschutz kaum eine Chance?, mimeo, University of Hagen, 2000-

B.S. FreY and F. OBerholzer-GeE (1996), Zum Konflikt zwischen intrinsischer Motivation und umweltpolitischer Instrumentenwahl, in: H. SIEBERT (ed.), Elemente einer rationalen Umweltpolitik, Mohr (Siebeck), Tübingen 1996, pp. $207-238$.

B.S. FREY (1972), Umweltökonomie, Vandenhoeck, Göttingen, $3^{\text {rd }}$ edition 1992.

B.S. FREY (1997), Markt und Motivation: Wie ökonomische Anreize die (Arbeits-)Moral verdrängen, Vahlen, München 1997.

B.S. FREY and F. SCHNEIDER (1978), An Empirical Study of Politico-Economic Interaction in the United States, Review of Economics and Statistics 60 (1978), pp. $174-183$.

B.S. FreY and F. SCHNEIDER (1978a), A Politico-Economic Model of the United Kingdom, Economic Journal 88 (1978), pp. 243 - 253.

B.S. FREY and F. SCHNEIDER (1979), An Econometric Model with an Endogenous Government Sector, Public Choice 34 (1979), pp. 29 - 43.

E. GAWEL (1994), Zur politischen Ökonomie von Umweltabgaben, Mohr (Siebeck), Tübingen 1994. 
E. GAWEL (1994a), Umweltpolitik zwischen Verrechtlichung und Ökonomisierung, ORDO 45 (1994), pp. $63-103$.

E. GAWEL (1995), Bürokratie, Theorie und Umweltverwaltung: Ökonomische Einsichten in verwaltungsrechtliches Handeln im Umweltschutz, Zeitschrift für Angewandte Umweltforschung 8 (1995), pp. $79-89$.

E. GAWEL (2001), Intrinsische Motivation und umweltpolitische Instrumente, Perspektiven der Wirtschaftspolitik 2 (2001), pp. 145 - 165.

L.H. GOULDER (1995), Environmental Taxation and the Double Dividend: A Reader's Guide, International Tax and Public Finance 2 (1995), pp. 157 - 183.

R.W. HAHN (1989), Economic Prescriptions for Environmental Problems: How the Patient Followed the Doctor's Orders, Journal of Economic Perspectives 3, Issue 2/1989, pp. 95 - 114.

B. HANSJÜRGENS (1998), The Sulfur Dioxide Allowance-Trading Program in the USA: Recent Developments and Lessons to be Learned, Environment and Planning C: Government and Policy 16 (1998), pp. $341-361$.

J. HelBig and J. VolKert (1999), Freiwillige Standards im Umweltschutz, Physica, Heidelberg 1999.

D.A. Hibbs (1977), Political Parties and Macroeconomic Policy, American Political Science Review 71 (1977), pp. 1467 - 1487.

D.A. Hibis (1992), Partisan Theory After Fifteen Years, European Journal of Political Economy 8 (1992), pp. $361-373$.

A.L. HiLlmAN and H.W. URSPRUNG (1994), Greens, Supergreens, and International Trade Policy: Environmental Concerns and Protectionism, in: C. CARRARO (ed.), The International Dimension of Environmental Policy, Kluwer, Dordrecht 1994, pp. 75 - 108.

F. HIRSCH (1976), The Social Limits to Growth, Harvard University Press, Cambridge (Mass.) 1976.

K. HolzingeR (1987), Umweltpolitische Instrumente aus der Sicht der Bürokratie: Versuch einer Anwendung der ökonomischen Theorie der Bürokratie, Vahlen, München 1987.

J. HoRBACH (1992), Neue politische Ökonomie und Umweltpolitik, Fischer, Frankfurt 1992.

M. Huxham und D. Sumner (1999), Emotion, Science and Rationality: The Case of the Brent Spar, Environmental Values 8 (1999), pp. 349 - 368.

IMAS (1995); Umfrageberichte von IMAS-International, IMAS-International, Linz 1995.

IMAS (1996); Umfrageberichte von IMAS-International, IMAS-International, Linz 1996.

P.L. Joskow, R. Schmalensee, and E.M. Bailey (1998), The Market for Sulfur Dioxide Emissions, American Economic Review 88 (1998), pp. 669 - 685.

P.L. Joskow and R. SCHMALENSEE (1998), The Political Economy of Market-Based Environmental Policy: The U.S. Acid Rain Program, Journal of Law and Economics 41 (1998), pp. 37 - 84.

S. Kelman (1981), What Price Incentives?, Economists and the Environment, Auburn House, Boston 1981.

G. KIRCHGÄSSNER (1992), Towards a Theory of Low-Cost Decisions, European Journal of Political Economy 8 (1992), S. 305 - 320.

G. KIRCHGÄSSNER (1994), Nationale und internationale Bestimmungsfaktoren der schweizerischen Mineralölpreise: Eine Anwendung der Kointegrationsanalyse, Schweizerische Zeitschrift für Volkswirtschaft und Statistik 130 (1994), pp. 575 - 598.

G. KIRCHGÄSSNER (1997), Nachhaltigkeit in der Umweltnutzung: Einige Bemerkungen, Zeitschrift für Umweltpolitik und Umweltrecht 20 (1997), S. 1 - 34. 
G. KIRCHGÄSSNER (1998), Ökologische Steuerreform: Utopie oder realistische Alternative, in: G. Krause-JunK (ed.), Steuersysteme der Zukunft, Duncker und Humblot, Berlin 1998, pp. 279 319.

G. KIRCHGÄSSNER (1999), Wirtschaftliche Auswirkungen von Energiesteuern auf kleine offene Volkswirtschaften: Theoretische Überlegungen und Simulationsergebnisse, in: F. SCHNEIDER (ed.), Internationale Strategien und Erfahrungen zur Neuorientierung der EU-Energiewirtschaft, Rudolf Trauner, Linz 1999, pp. 153 - 181.

G. KIRCHGÄSSNER (2000), Die Bedeutung moralischen Handelns für die Umweltpolitik, GAiA 9 (2000), pp. $41-49$.

G. KIRCHGÄSSNER and K. KÜBLER (1992), Symmetric or Asymmetric Price Adjustment in the Oil Market?, An Empirical Analysis of the Relations Between International and Domestic Prices in the Federal Republic of Germany, 1972 - 1989, Energy Economics 14(1992), pp. 171 - 185.

G. KIRCHGÄSSNER and W.W. POMMEREHNE (1993), Low-Cost Decisions as a Challenge to Public Choice, Public Choice 77 (1993), pp. 107 - 115.

G. KIRCHGÄSSNER, U. MÜLLER and M.R. SAVIOZ (1998), Ecological Tax Reform and Involuntary Unemployment: Simulation Results for Switzerland, Schweizerische Zeitschrift für Volkswirtschaft und Statistik 134 (1998), pp. 329 - 353.

G. MAIER-RIgAUD (1996), Für eine ökologische Wirtschaftsordnung, Jahrbuch für Ökologie 1996, pp. $71-79$.

A. MAIER ZU HIMMERN and G. KIRCHGÄSSNER (1995), Umweltschutz und internationale Wettbewerbsfähigkeit, in: M. JOCHIMSEN and G. KIRCHGÄSSNER (eds.), Schweizerische Umweltpolitik im internationalen Kontext, Birkhäuser, Basel, 1995, pp. 43 - 76.

A. Michaelowa (1998), Übertragung des Demokratiemodells der neuen Politischen Ökonomie auf die Klimapolitik, Zeitschrift für Umweltpolitik und Umweltrecht 21 (1998), pp. 463 - 491.

J. Minsch, A. Eberle, B. MeIER and U. SCHNEIDEWIND (1996), Mut zum ökologischen Umbau: Innovationsstrategien für Unternehmen, Politik und Akteurnetze, Birkhäuser, Basel 1996.

W.A. Niskanen (1968), The Peculiar Economics of Bureaucracy, American Economic Review, Papers and Proceedings, 58.2 (1968), pp. 293 - 305.

W.A. NisKANEN (1971), Bureaucracy and Representative Government, Chicago University Press, Chicago 1971.

OECD (1997), Environmental Policies and Employment, Paris 1997.

H.E. OTT and W. SACHS (2000), Ethical Aspects of Emissions Trading, Wuppertal Institute for Climate, Environment and Energy, Wuppertal Paper No. 110, September 2000.

M. PALdAM (1997), Political Business Cycles, in: D.C. Mueller (ed.), Perspectives on Public Choice: A Handbook, Cambridge University Press, Cambridge (UK) 1997, pp. 342 - 370.

D.W. PeARCE (1991), The Role of Carbon Taxes in Adjusting to Global Warming, Economic Journal 101 (1991), pp. $938-948$.

K. RenNings, K.L. Brockmann and H. BergmanN (1997), Voluntary Agreements in Environmental Protection: Experiences in Germany and Future Perspectives, Business Strategy and the Environment 6 (1997), pp. 245 - 263.

F. SCHNEIDER (1997), Einige Bemerkungen zu den Umsetzungsproblemen ökologisch-orientierter Wirtschaftspolitik aus der Sicht der Neuen Politischen Ökonomie, in: H. SCHMID und T. SLEMBECK (eds.), Finanz- und Wirtschaftspolitik in Theorie und Praxis, Haupt, Bern et al. 1997, pp. 467 -486 .

F. SCHNEIDER (1998), Induzieren ökologische Steuerreformen einen Lenkungseffekt oder nur volle Staatskassen?, IAW-Mitteilungen 26 (1998). 
F. SCHNEIDER and J. VOLKERT (1999), No Chance for Incentive-Oriented Environmental Policies in representative Democracies? A Public Choice Analysis, Ecological Economics 31 (1999), pp. 123 $-138$.

CH.M. SchOlz (2000), Environmental Tax Reforms and the Double Dividend: A Theoretical and Empirical Analysis for Germany, Mohr Siebeck, Tübingen 2000.

T. Secombe-Hett (2000), Market-Based Instruments: If They're so Good, Why Aren't They the Norm?, World Economics 1 (2000), pp. 101 - 126.

F. SÖLLNER (1993), Neoklassik und Umweltökonomie, Zeitschrift für Umweltpolitik und Umweltrecht 16 (1993), pp. $431-460$.

E. StAeHELIN-WitT and A. SpillmanN (1994), Emissionshandel: Erfahrungen in der Region Basel und neue Ansätze, Zeitschrift für Umweltpolitik und Umweltrecht 17 (1994), S. 207 - 223.

G.T. Svendsen (1999), U.S. Interest Groups Prefer Emission Trading: A New Perspective, Public Choice 101 (1999), pp. 109 - 128.

H.W. URSPRUNG (1992), The Political Economy of Environmental Decision Making, University of Konstanz, Sonderforschungsbereich 178 "Internationalisierung der Wirtschaft", Working Paper No. 176, Series II, May 1992.

T.R. TYLOR (1990), Why People Obey the Law, Yale University Press, New Haven 1990.

J.-R. TYRAN and L.P. FeLD (2001), Why People Obey the Law: Experimental Evidence from the Provision of Public Goods, mimeo, University of St. Gallen, May 2001.

H. WeCK-HANnemanN (1994), Die politische Ökonomie der Umweltpolitik, in: R. BARTEL und F. HACKL (eds.), Einführung in die Umweltpolitik, Vahlen, München 1994, pp. 101 - 117.

H. WeCK-Hannemann and B.S. Frey (1995), Are Incentive Instruments As Good As Economists Believe? Some New Considerations, in L. Bovenberg and S. CNOSSEN (eds.), Public Economics and the Environment in an Imperfect World, Kluwer, Boston 1995, pp. 173 - 186.

K.W. ZIMMERMANN (1996), Zur politischen Ökonomie von Ökosteuern, ORDO 47 (1996), pp. 169 194. 